\title{
Discourse on Leadership and Gender Awareness in Higher Education Publications: A View through the Lens of Feminist Phase Theory
}

\author{
Adrienne E. Hyle \\ Stillwater, OK, USA \\ adrienne.hyle@icloud.com
}

\author{
Peggy M. Delmas \\ University of South Alabama, \\ Mobile, AL, USA \\ pdelmas@southalabama.edu
}

\author{
Bernita L. Krumm \\ Oklahoma State University, Stillwater, OK, USA \\ bernita.krumm@okstate.edu
}

\begin{abstract}
Using Feminist Phase Theory (FPT) as our analytical framework, we studied the status of gender awareness and influence in higher education leadership development trends in four premier higher education journals for the years 2008, 2011, and 2014. Our analysis was accomplished through the review of articles and book reviews published in two US and two international journals:

Higher Education (Netherlands), Higher Education Quarterly (UK), Journal of Higher Education (US), and The Review of Higher Education (US). Study results indicated progress toward a multifocal set of perspectives in which gender was not an issue; rather other concerns such as social justice or diversity were the focus.

Data also indicated that while gender was no longer a specific focus of the literature, it was still an underlying concern. Gender and leadership are still being examined, intentionally or not. An additional finding revealed through the study of these journals is a lack of research about leadership in higher education, particularly in the US. A focus on understanding leadership does not appear to be a priority among this higher education community.
\end{abstract}

Keywords: Feminist Phase Theory, gender, higher education administration, higher education leadership, leadership

Material published as part of this publication, either on-line or in print, is copyrighted by the Informing Science Institute and Preeminent Leadership and Research Solutions, LLC. Permission to make digital or paper copy of part or all of these works for personal or classroom use is granted without fee provided that the copies are not made or distributed for profit or commercial advantage AND that copies 1) bear this notice in full and 2) give the full citation on the first page. It is permissible to abstract these works so long as credit is given. To copy in all other cases or to republish or to post on a server or to redistribute to lists requires specific permission and payment of a fee. Contact Publisher@,InformingScience.org to request redistribution permission.

\section{Introduction}

Gender parity in higher education administration has not been achieved. Despite Title IX, ensuing affirmative action legislation, and multiple waves of feminist research and scholarship, women in the US remain underrepresented in administration (Bornstein, 2008; Dominico, Fried, \& Zeger, 2009; Eagly \& Carli, 2007; Glazer-Raymo, 1999, 2008; Kel- 
lerman \& Rhode, 2007; Kolb, Williams, \& Frohlinger, 2004; National Leadership Network, 1992; Nidiffer, 2000, 2003; Nidiffer \& Bashaw, 2001; Schmuck, 1987, 1993; Wolverton, Bower, \& Hyle, 2009, Zichy, 2001). This phenomenon exists as well in Great Britain (Bagilhole, 2002; Brown, 1997; Eggins, 1997; Equality Challenge Unit, 2014; King, 1997; White, Bagilhole, \& Riordan, 2012). In Australian universities, a patriarchal system still operates (Keamy, 2008). Friedan's (1963) observation about women's "struggle to be human in a gendered world ... is still worth talking about" and over 50 years later still afflicts us today (Shteir, 2013, p. 1). Women have still not "arrived."

Research on the underrepresentation of women in higher education administration can be situated in the broader literature that examines and problematizes the marginalization of the study of minorities (Baffoe, Asimeng-Boahene, \& Ogbuagu, 2014; Hune, 1998; Hunt \& Harrington, 2010; $\mathrm{Ng}$, Lee, \& Pak, 2007; Stanley, 2007), and other traditionally excluded groups (Kumashiro et al., 2005: Peña, 2014; Phillips, Ingram, Smith, \& Mindes, 2003; Van Voorhis \& Wagner, 2001) in peer-reviewed journals. This underrepresentation is not limited to higher education administration; rather, it crosses multiple venues. With specific regard to women, researchers have noted a gender gap in academic publishing, both generally (Leahy, 2006; Ward \& Grant, 1996) and within specific disciplines or fields, including counselor education (Buffalino Roland, \& FontanesiSeime, 1996), ecology (Martin, 2012), geography (Rigg, McCarragher, \& Krmenec, 2012) leisure studies (Aitchison, 2001), library science (Terry, 1996), physical therapy (Kaufman \& Chevan, 2011), political science (Evans \& Bucy, 2010; Mathews \& Anderson, 2001), and medicine (Barnett et al., 1998, Jagsi et al., 2006).

The cyclical nature of research and theory development reflects and influences the practice of higher education leadership. If theory and practice in higher education leadership are to maintain congruence, the study of leadership must continue to change as the profession itself evolves. Imposed paradigms of belief that do not reflect the reality of practice must change. However, as Parsons and Ward (2001) wrote, "Such challenges are unlikely given that disciplinary power is often concomitant with reproduction. . . . Academics are disciplined not to recognize the subtle, unconscious sexism that permeates the academy" (pp. 56-57). Herr Van Nostrand (1993) termed it "territorial sexism" which "at its most extreme . . . allows no space at all for one gender - a form of bias by omission" (p. 38).

In terms of leadership and gender, this means that traditional paradigms may not be challenged or even acknowledged as outdated. However, messages that are disparaging of gender or neglectful or devoid of gender considerations are detrimental to the profession and must be addressed. "What must be avoided is perpetuating forms of scholarship and practice that trap women into maintaining traditional sex stereotypes or adding new ones, and conspiring in their own oppression" (Twombly, 1991, p. 17). Understanding current conceptions of higher education leadership can assist in determining new directions for research on the disciplinary development of leadership and gender.

Feminist Phase Theory (FPT), as developed by Tetreault (1985), is a five phase evaluation model developed for the purpose of classifying the evolution in thought about women in traditional disciplines (Townsend, 1993; Twombly, 1993). The phases describe levels of awareness ranging from thought devoid of women to thought of integration where men and women relate to and complement one another. The strength of FPT is that it provides an organizing framework for examining the gender awareness of a discipline through review of its literature, ultimately revealing "... where one has been, where one is, and where one might be going" (Tetreault, 1985, p. 366).

In addition to examining the usefulness of Feminist Phase Theory (FPT) for understanding levels of gender awareness in leadership research, the findings of this study could help inform practice 
for higher education leadership programs possibly challenging unconscious sexism and underlying assumptions of program content and delivery. Study findings may also provide fodder for editors of journals related to higher education administration. Through awareness of leadership content within their articles and book reviews, editors may decide to refocus journal content on leadership and gender. Additionally, scholars who publish in the areas of gender, higher education administration, and higher education leadership may find new direction for their research.

\section{Purpose}

Traditionally the newest and most currently investigated research explorations of leadership are found in research journals (Hutchinson \& Lovell, 2004), those founded on the peer review process. At the same time, more research is being reported in non-peer reviewed research-based texts, edited volumes, and scholar authored publications. The book review process in place in many research journals, unlike peer review, starts with a recommended selection list of cur$\mathrm{rent} / \mathrm{new}$ books thought to be influential. We wondered what realities about leadership and gender would be revealed by an examination framed by Feminist Phase Theory of both leadership research journal content and the same journals' selected book reviews.

Using the evaluative classification schema of Feminist Phase Theory (FPT) (Tetreault, 1985, 1987a, 1987b), we sought to:

1) examine leadership content (what), structure (who), and methodology (how) as reflected in journal articles and book reviews published in the years 2008, 2011, and 2014 in the following four research-based journals focused on higher education:

Higher Education (INT - Netherlands), Higher Education Quarterly (INT - UK), Journal of Higher Education (US), and The Review of Higher Education (US);

2) cast that data in terms of FPT's five developmental awareness levels; and

3) given findings, generate advice for leadership development.

\section{Orienting Theoretical Framework}

Feminist Phase Theory, Tetreault's (1985, 1987a, 1987b) five phase classification model, was designed to evaluate the awareness levels of thought about women in academic disciplines. "The classification schema was developed by reviewing the literature in anthropology, history, literature, and psychology; by identifying five common phases of thinking about women; and by providing examples of questions commonly asked about women in each discipline" (Tetreault, 1985, p. 366).

FPT (McIntosh, 1983; Schuster \& Van Dyne, 1984; Tetreault, 1985; Twombly, 1991) presented a paradigm for documenting the ongoing process of the inclusion of women into various disciplines, recording the steps towards a more gender-balanced view of what is worth knowing in higher education leadership, and providing a means to evaluate the "content, structure, and methodology" of the discipline (Tetreault, 1985, p. 380). Twombly (1991) explained, "Such an analysis is a necessary and helpful precursor to setting a future research agenda as well as a guide to changed practice" (p. 14).

FPT is an especially helpful and important analytic tool because:

1) It is critical of existing social structures and ways of perceiving them,

2) It serves as a corrective mechanism by providing an alternative viewpoint and data to substantiate it, and 
3) It starts to lay the groundwork for the transformation of knowledge. (Eichler, 1980, p. 9)

"Transforming knowledge ... involves changing what and how we think and leads us to begin to change who and how we are in the world we share" (Minnich, 1990, p. 80). And, "changing what we study and know about women will change women's and men's lives" (Andersen, 1988, p. 39).

\section{FPT components}

FPT focuses on three components important in the categorization of the stages of thought about gender in academic disciplines - content, structure, and methodology. "Content" is defined as the array of topics or components associated with the disciplinary knowledge base. "Structure" is the organization of the tasks related to the knowledge base, i.e., roles, group dynamics, and relationships. "Methodology" focuses on the ways in which disciplinary work is accomplished. In this research project, FPT provided the framework to analyze leadership knowledge generation and awareness in terms of gender (Tetreault, 1985).

\section{The Five Phases of FPT}

In the first phase of the theory, male scholarship, thinking "assumes that the male experience is universal, that it is representative of humanity and that it constitutes a basis for generalizing about all human beings" (Tetreault, 1985, p. 367). Men are the objects and subjects of administration; the thoughts, experiences, and behaviors of women were not considered. All categories of thought are written by men about men, and the male model is accepted as the norm (Tetreault, 1987b). "What is at issue is the practice of studying male behavior and then assuming that the results are appropriate for understanding all behavior" (Shakeshaft \& Nowell, 1984, p. 188). Leadership was whatever was practiced by men. What was known about the male experience went unquestioned and was assumed to apply to all humans.

Phase two, compensatory scholarship, recognizes the absence of women, although maleness is still considered the standard for humanness. In this phase, there is a search for women, but male thought is still the norm. Traditional structures are not confronted or disputed. Theories are still constructed from men studying other men, causing the majority of women to be different and thus thought of as inferior. When women do not match the male's paradigm of the world, it is not seen as a problem with extant theory but a sign of their weakness (Schuster \& Van Dyne, 1984; Tetreault, 1985). However, questions concerning the absence of women are starting to be asked. The few women noted are exceptional, outside the norm by gender, novelties among the males (Tetreault, 1987a).

Efforts to include women begin in bifocal scholarship, phase three, as women's efforts to overcome under-representation are recognized; however, the male experience was seen as more appropriate. In this phase, women are no longer thought of as substandard, and the differences between men and women are examined (Lougee, 1981; Tetreault, 1985). This phase continues to emphasize "men thinking and women being thought about" (Tetreault, 1985, p. 374). Scholarship of this type tends to present women as a homogenous group having universally different characteristics from men. As a result, differences among women are overlooked and new stereotypes replace the old ones (Twombly, 1993).

In the fourth phase, feminist scholarship, the spotlight turns to women's endeavors, not men's, as the measure of importance. Things that had little significance in the past, such as the everyday lives of women, assume new significance (Tetreault, 1985). The life experiences of women leaders and their autobiographies illuminate the perceptions of women and women's perceptions of themselves. Knowledge about men is neither desired nor of interest. The essence of literature during this phase focuses on the "institutional processes and practices which treat women differently 
from men" (Schmuck, 1987, p. 5). In this phase, by paying attention to women as subjects and objects of study, scholars have found that extant theories are no longer adequate (Schmuck, 1987, p. 3).

A fully developed perspective that unites men's and women's experiences into a holistic view of human experience is indicative of the final phase of Feminist Phase Theory, multifocal or relational scholarship. This phase is characterized by the question, "Is gender always a difference that makes a difference?" Thinking in this fifth phase assumes that femininity and masculinity are along a continuum of humanness, and both can be used to define a person (Tetreault, 1985). Phase five is "difficult to describe because it remains largely unrealized" (Grunig, 2000, p. 94). It continues many of the explorations started in the feminist phase and begins "a reconceptualization of the human experience as a continuum (rather than dichotomy) between the masculine and feminine. Multifocal research has the potential to redefine a field" (Grunig, 2000, p. 94); it starts to look at how men's and women's experiences converge (Tetreault, 1985). Individuals viewing administration from a phase five, multifocal or relational perspective do not need to reference gender; gender is not an issue. Issues of class, race and social justice are the focus of administrative issues and concerns.

\section{Procedures}

Specific data needs and sources as well as analysis strategies emerged from the purposes of this study. Each is detailed below.

\section{Data needs and sources}

"Scholarly publishing is a critical activity for the development of academic careers and for the growth of knowledge" (Ward \& Grant, 1996, p. 172). And,

Professional journals serve an important function within most disciplines. They offer a mechanism by which professionals communicate ideas, stimulate discussion (as well as controversy), and share information, often in the form of research findings. (Hutchinson \& Lovell, 2004, p. 383)

To understand the disciplinary development of leadership and gender, we examined peerreviewed "leadership" articles and reviews of "leadership" books published in the years 2008, 2011, and 2014. Beginning our research in 2008, we chose to sample Higher Education (Netherlands; HE), Higher Education Quarterly (UK; HEQ), Journal of Higher Education (US; JHE), and The Review of Higher Education (US; RevHE) every three years in order to get a "snap shot" of the data trends. We selected these journals because of their high readership across higher education faculty. In addition, these journals (singularly, in combination or with other education/research journals) have served as data sources over the past 30 years for higher education scholars including, for example, Silverman (1985, 1987), Budd (1988), Milam (1991), Townsend (1993), Hutchinson and Lovell (2004), Hart (2006), Donaldson and Townsend (2007), Bray and Major (2011), and most currently Wells, Kolek, Williams, and Saunders (2015).

To maximize possible data sources, we independently reviewed the tables of contents and abstracts, and collected copies of all articles and book reviews that suggested subject matter linked to higher education leaders, administrators, or leadership, and a focus on the discipline of administration or leadership in any way. Articles and book reviews of nebulous content, those for which it was unclear whether or not they related to leadership, leaders, or administrators, were included rather than excluded. We then compared assessments and negotiated agreement on the list of articles and book reviews to analyze (Chuppa-Cornell, 2005; Silverman, 1987; Tight, 2007, 2008). 


\section{Data analysis}

After reaching agreement on the list of articles and book reviews to be analyzed, we constructed a grid to record analytical findings and entered demographic data for all selected articles and book reviews. We then independently analyzed the content of the articles and book reviews and coded this data in terms of the content, structure, and methodology of leadership as well as FPT phase. We compared assessments and negotiated agreement when needed.

Content ("what") was operationalized as the substance of a leader's work (i.e., leadership), the topic or subject matter (i.e., evaluation), or the areas that would have been included in a leader's job description (i.e., management). We defined structure as the relationship of content to the organization, the formal leadership position in the organization (i.e., dean, provost). In other words, structure was "who" did "what" in the organization and the ways in which they fit together to make a whole. Methodology described the system of principles (philosophy: i.e., constructivism), practices (behaviors: i.e., open door policy), and procedures (ways of doing: i.e., data-driven decision-making) applied to the process of leadership; the "how" of administration.

In terms of FPT awareness phases, generally, the category of male focused on generalizations about men, thought to hold true for women. Compensatory still focused on men, but with exceptions that referred to women. Bifocal admitted that both women and men were leaders and their experiences were different. Feminist focused only on women, their lives and their leadership. In multifocal (relational), gender was not an issue; other concerns such as social justice or diversity were the focus.

We reviewed our independent findings and negotiated agreement on the categorizations for each article and book review. When there was disagreement on initial coding, we conducted an additional review to reach consensus.

\section{Findings}

From our review, multiple findings emerged. Summaries of journal demographics and of journal article and book review FPT content, structure, method and gender awareness levels follow.

Journal, article, and book review demographics. We reviewed the content of four peer-reviewed journals, two US and two international (see Table 1). Higher Education (HE) publishes four to five times the number of articles published yearly in the other reviewed journals and comprised $58 \%$ of the articles reviewed in 2008, 2011 and 2014.

Recognized as the leading international journal on higher education studies, this publication examines educational developments throughout the world in universities, polytechnics, colleges, and vocational and education institutions. It reports on developments in both public and private higher education sectors. (Springer, n.d.)

Higher Education Quarterly (HEQ), the other international journal reviewed, consistently publishes 21 articles yearly and is the journal for the Society for Research into Higher Education (SRHE) with members in every continent. Higher Education Quarterly

occupies a critical space in promoting research into higher education policy and practice internationally. Its remit includes, for instance, institutional approaches to the student experience, management and leadership; system-wide issues such as student funding and widening participation; and international responses to global market environments...The journal is unique in bringing together issues arising from academic policy and practice and thereby serving a broadly based readership. (Wiley, n.d.)

The Journal of Higher Education (JHE) is a publication of the Ohio State University Press. JHE is promoted through the Association for the Study of Higher Education's (ASHE) web site and 
ASHE members are offered a discount on the publication. JHE is "the leading scholarly journal on the institution of higher education. Articles combine disciplinary methods with critical insight to investigate issues important to faculty, administrators, and program managers" (Association for the Study of Higher Education, n.d.).

The Review of Higher Education (RevHE) is published by Johns Hopkins University Press and is sponsored by the Association for the Study of Higher Education.

Considered one of the leading research journals in the field, The Review keeps scholars, academic leaders, and public policymakers abreast of critical issues facing higher education today. The Review of Higher Education is the official journal of the Association for the Study of Higher Education (ASHE). (Johns Hopkins University Press, n.d.)

Table 1: Journal overviews

$\begin{array}{lcc}\text { JOURNAL COUNTRY ISSUES } & \text { AFFILIATION } \\ \text { YEARLY } & \end{array}$

\begin{tabular}{cccc}
\hline Higher Education & Netherlands & 12 & None \\
\hline Higher Education Quarterly & United Kingdom & 4 & $\begin{array}{c}\text { Society for Research into } \\
\text { Higher Education }\end{array}$ \\
\hline Journal of Higher Education & US & 6 & None \\
\hline The Review of Higher Education & US & 4 & $\begin{array}{c}\text { Association for the Study of } \\
\text { Higher Education }\end{array}$ \\
\hline
\end{tabular}

Table 2 summarizes the numbers of articles published in each of the journals reviewed in 2008, 2011, and 2014 and the numbers of articles assessed to be dealing with leadership, leaders, or administration. We began with a total of 477 articles for 2008, 2011, and 2014 in the four journals reviewed. Given our focus (higher education leaders, leadership, or the discipline of administration), a scant nine articles ( $2 \%$ ) met our criteria. Six of the nine articles were published in 2008, and two were published in 2011 and one in 2014. Seven (75\%) of the articles were published in international journals.

Table 2: Article demographics

\begin{tabular}{lccccccc}
\hline $\begin{array}{l}\text { TOTAL } \\
\text { ARTICLES }\end{array}$ & $\begin{array}{c}\text { HE } \\
\text { (NETH) }\end{array}$ & $\begin{array}{c}\text { HEQ } \\
\text { (UK) }\end{array}$ & INT'L & $\begin{array}{c}\text { JHE } \\
\text { (US) }\end{array}$ & $\begin{array}{c}\text { RevHE } \\
\text { (US) }\end{array}$ & US & TOTAL \\
\hline 2008 & 82 & 21 & 103 & 24 & 15 & 39 & 142 \\
\hline 2011 & 81 & 21 & 102 & 27 & 22 & 49 & 151 \\
\hline 2014 & 115 & 21 & 136 & 30 & 18 & 48 & 184 \\
\hline \multirow{2}{*}{ Totals } & 278 & 63 & 341 & 81 & 55 & 136 & \\
& $(58 \%)$ & $(13 \%)$ & $(71 \%)$ & $(17 \%)$ & $(12 \%)$ & $(29 \%)$ & 477 \\
\hline
\end{tabular}

\begin{tabular}{lccccccc}
\hline Selected & \multicolumn{7}{l}{} \\
\hline 2008 & $1(1 \%)$ & $3(14 \%)$ & $4(4 \%)$ & $2(8 \%)$ & 0 & $2(1 \%)$ & $6(1 \%)$ \\
\hline 2011 & $1(1 \%)$ & $1(5 \%)$ & $2(2 \%)$ & 0 & 0 & 0 & $2(1 \%)$ \\
\hline 2014 & $1(1 \%)$ & 0 & $1(<1 \%)$ & 0 & 0 & 0 & $1(<1 \%)$ \\
\hline Totals & $3(1 \%)$ & $4(6 \%)$ & $7(2 \%)$ & 2 & 0 & $2(1 \%)$ & $9(2 \%)$ \\
\hline
\end{tabular}


In terms of author gender, 4 (45\%) of the articles were first- or sole-authored by women, 5 (55\%) by men. We confirmed authors' genders by referencing pronouns used on professional web sites. Both women and men worked independently and collaboratively on the research reported. US published women and men (1 each for the years reviewed) worked independently. Internationally, the women who published leadership articles and collaborated, collaborated with both men and women. The men who published leadership articles and collaborated, collaborated with men. Across the groups, more women worked independently than collaboratively ( 3 of 4$)$; more men than women worked collaboratively ( 3 of 5). Table 3 presents these demographics.

Table 3: Article author gender

\begin{tabular}{lcccc|c}
\hline \multicolumn{5}{c}{ INT'L } & \multicolumn{2}{c}{ US } \\
\hline Authors & HE & HEQ & JHE & RevHE & Total \\
\hline Female & $2014(1)$ & $2008(1)$ & $2008(1)$ & - & \\
Female/Female & - & - & - & - & 4 \\
Female/Male & - & - & - & - & $(45 \%)$ \\
Female/Both & $2008(1)$ & - & - & - & \\
\hline Male & $2011(1)$ & - & $2008(1)$ & - & \\
Male/Male & - & $2008(2)$ & - & - & 5 \\
Male/Female & - & $2011(1)$ & - & - & $(55 \%)$ \\
Male/Both & - & & - & - & \\
\hline Article Totals & $3(33 \%)$ & $4(45 \%)$ & $2(22 \%)$ & 0 & 9 \\
\hline
\end{tabular}

The articles meeting our criteria examine a range of leadership actors (pro-vice-chancellors, presidents, deans, department heads) in a variety of college and university settings. Article content focused on leadership roles and the strategies of managing relationships and advancing agendas. Research methods used in these nine articles were predominately qualitative interviews, seven of the nine. One study employed anova and t-tests; another was an opinion piece.

Table 4 summarizes the number of book reviews published in each of the journals reviewed in 2008, 2011, and 2014 and the number of book reviews determined to be dealing with leaders, leadership, or administration. Of the 180 book reviews published during our review period, the majority of book reviews, $86 \%$, were published in US journals, with RevHE publishing three or more times that of JHE in any year reviewed. Across both US and international contexts, 80 book reviews were published in 2008, with a 25\% decrease to 60 book reviews in 2011 and another $25 \%$ decrease to 40 book reviews in 2014 .

Assessing the 180 book reviews yielded a total of 16 with a focus on leaders, leadership, or administration. The international journals provided only two (13\%) of the reviews, both published in 2011, one each in HE and HEQ. The US journals provided 14 (87\%) of the book reviews, with eight published in 2008, two published in 2011, and four published in 2014. RevHE had the most reviews selected at 10, followed by JHE with four reviews selected. As may be expected, the reviews selected from the international journals focused on titles which examined higher education leadership from a global perspective, seeking commonalities among the models or conceptions of leadership. The reviews selected from domestic journals covered titles for which the setting was the U.S., with presidencies and ethics in leadership being the most common areas of focus. 
Table 4: Book review demographics

\begin{tabular}{cccccccc}
\hline $\begin{array}{c}\text { TOTAL } \\
\text { BOOK } \\
\text { REVIEWS }\end{array}$ & $\begin{array}{c}\text { HE } \\
\text { (NETH) }\end{array}$ & $\begin{array}{c}\text { HEQ } \\
\text { (UK) }\end{array}$ & $\begin{array}{c}\text { INT'L } \\
\text { TOTALS }\end{array}$ & $\begin{array}{c}\text { JHE } \\
\text { (US) }\end{array}$ & $\begin{array}{c}\text { RevHE } \\
\text { (US) }\end{array}$ & $\begin{array}{c}\text { US } \\
\text { TOTALS }\end{array}$ & TOTAL \\
\hline 2008 & 2 & 1 & 3 & 19 & 58 & 77 & 80 \\
\hline 2011 & 9 & 8 & 17 & 11 & 32 & 43 & 60 \\
\hline 2014 & 4 & 0 & 4 & 6 & 30 & 36 & 40 \\
\hline Totals & $15(8 \%)$ & $9(5 \%)$ & $24(13 \%)$ & $36(20 \%)$ & $120(66 \%)$ & $156(86 \%)$ & 180 \\
\hline
\end{tabular}

\begin{tabular}{cccccccc}
\hline Selected & \multicolumn{7}{c}{} \\
\hline 2008 & 0 & 0 & 0 & $2(11 \%)$ & $6(10 \%)$ & 8 & 8 \\
\hline 2011 & $1(11 \%)$ & $1(13 \%)$ & $2(12 \%)$ & 0 & $2(6 \%)$ & 2 & 4 \\
\hline 2014 & 0 & 0 & 0 & $2(33 \%)$ & $2(7 \%)$ & 4 & 4 \\
\hline Totals & $1(7 \%)$ & $1(11 \%)$ & $2(8 \%)$ & $4(11 \%)$ & $10(8 \%)$ & $14(9 \%)$ & $16(9 \%)$ \\
\hline
\end{tabular}

Because of the scant number of book reviews dealing with titles related to leadership or administration, we wondered if there were simply not many books being published in these areas.

Through a review of Bowker Books in Print (Bowker, n.d.), a bibliographic database, we generated a list of all English language books published between 2006-2014 identified with keywords "administration," "higher education leadership," or "higher education management." We included the years 2006-2007 in this search because some of the books reviewed in the four research journals were published as early as 2006 . Our analysis yielded 363 books total and 55 titles dealing with administration or higher education leadership. Books on leadership in higher education were indeed being published, at a rate of roughly seven titles per year, for the eight-year period investigated.

\section{FPT Components - Content, Structure and Method}

In terms of FPT content (what), only nine of 477 (2\%) articles reviewed in the four journals in 2008, 2011, and 2014 explored leadership. For book reviews in the same journals over the same years, 16 of 180 (9\%) explored leadership. Clearly, leadership was not the dominant topic of research or publications.

Article structure, the "who" of leadership, revealed a focus on top level university leaders including pro-vice-chancellors, presidents and deans (6 of 9; see Table 5). Academic or university leaders in general were the structure focus of three articles (see Table 5), all published in international journals.

FPT methodology, or how the work of administration was accomplished, was operationalized in terms of a focus on leadership principles (beliefs/philosophy), practices (behaviors), and/or procedures (ways of doing). Most articles presented multiple methods; all but three articles outlined principles and leadership practices or practices and ways to set them up procedurally. There was no clear pattern or focus across the nine articles or journals. For purposes of this research, the structure and methodology presented in the books reviewed was not assessed. Our assessment focused on each book reviewer's presentation of levels of gender awareness. 
Table 5: Article FPT structure, method and phase/level of gender awareness

\begin{tabular}{|c|c|c|c|c|}
\hline JOURNAL & ARTICLE TITLE & $\begin{array}{l}\text { STRUCTURE } \\
\text { - WHO }\end{array}$ & $\begin{array}{l}\text { METHOD } \\
\text { - WHAT }\end{array}$ & $\begin{array}{c}\text { FPT PHASE/LEVEL } \\
\text { OF GENDER } \\
\text { AWARENESS }\end{array}$ \\
\hline JHE & $\begin{array}{l}\text { Proscriptive norms for aca- } \\
\text { demic deans: Comparing fac- } \\
\text { ulty expectations across insti- } \\
\text { tutional and disciplinary } \\
\text { boundaries }\end{array}$ & Deans & Practices & $\begin{array}{l}\text { Phase } 5-\text { no gender } \\
\text { noted }\end{array}$ \\
\hline JHE & $\begin{array}{l}\text { Understanding leadership } \\
\text { strategies for addressing the } \\
\text { politics of diversity }\end{array}$ & $\begin{array}{l}\text { Presidents and } \\
\text { VPs }\end{array}$ & $\begin{array}{l}\text { Practices } \\
\text { Procedures }\end{array}$ & $\begin{array}{l}\text { Phase } 3 \text {, gender not } \\
\text { part of selection crite- } \\
\text { ria but included and } \\
\text { skewed from national } \\
\text { norms }\end{array}$ \\
\hline INT'L & $\begin{array}{l}\text { Creating a web of support: an } \\
\text { important leadership strategy } \\
\text { for advancing campus diversi- } \\
\text { ty }\end{array}$ & $\begin{array}{l}\text { Presidents and } \\
\text { VPs }\end{array}$ & $\begin{array}{l}\text { Practices } \\
\text { Procedures }\end{array}$ & $\begin{array}{l}\text { Phase 3, President } \\
\text { Araneae - used "she" } \\
\text { throughout }\end{array}$ \\
\hline $\begin{array}{l}\text { HEQ } \\
\text { INT'L }\end{array}$ & $\begin{array}{l}\text { Tensions in higher education } \\
\text { leadership: Towards a multi- } \\
\text { level model of leadership } \\
\text { practice }\end{array}$ & $\begin{array}{l}\text { UK University } \\
\text { leaders }\end{array}$ & $\begin{array}{l}\text { Principles } \\
\text { Practices }\end{array}$ & $\begin{array}{l}\text { Phase } 5-\text { no gender } \\
\text { noted }\end{array}$ \\
\hline $\begin{array}{l}\text { HEQ } \\
\text { INT'L }\end{array}$ & $\begin{array}{l}\text { Not enough science or not } \\
\text { enough learning? Exploring } \\
\text { the gaps between leadership } \\
\text { theory and practice }\end{array}$ & Leadership & Principles & $\begin{array}{l}\text { Phase } 5-\text { no gender } \\
\text { noted }\end{array}$ \\
\hline $\begin{array}{l}\text { HEQ } \\
\text { INT'L }\end{array}$ & $\begin{array}{l}\text { Academics or executives? } \\
\text { Continuity and change in the } \\
\text { roles of pro-vice-chancellors }\end{array}$ & $\begin{array}{l}\text { Pro-vice- } \\
\text { chancellors }\end{array}$ & $\begin{array}{l}\text { Practices } \\
\text { Procedures }\end{array}$ & $\begin{array}{l}\text { Phase } 5 \text { - no gender } \\
\text { noted }\end{array}$ \\
\hline INT'L & $\begin{array}{l}\text { Conceiving land grant univer- } \\
\text { sity community engagement as } \\
\text { adaptive leadership }\end{array}$ & $\begin{array}{l}\text { University } \\
\text { faculty and } \\
\text { officials }\end{array}$ & $\begin{array}{l}\text { Principles } \\
\text { Practices } \\
\text { Procedures }\end{array}$ & $\begin{array}{l}\text { Phase } 5 \text {, no gender } \\
\text { noted, "the leader will } \\
\text { engage actively and } \\
\text { successfully in their } \\
\text { own adaptive work" }\end{array}$ \\
\hline INT'L & $\begin{array}{l}\text { Development of manager- } \\
\text { academics at institutions of } \\
\text { higher education in Catalonia }\end{array}$ & $\begin{array}{l}\text { Presidents, } \\
\text { Deans, De- } \\
\text { partment } \\
\text { chairs }\end{array}$ & $\begin{array}{l}\text { Practices } \\
\text { Procedures }\end{array}$ & $\begin{array}{l}\text { Phase } 3 \text { - "his or her" } \\
\text { "a person's perfor- } \\
\text { mance" } \\
\text { (Jon, department head; } \\
\text { Alicia, department } \\
\text { head) }\end{array}$ \\
\hline $\begin{array}{l}\text { HE } \\
\text { INT'L }\end{array}$ & $\begin{array}{l}\text { The many faces of research } \\
\text { profiling: academic leaders' } \\
\text { conceptions of research steer- } \\
\text { ing }\end{array}$ & $\begin{array}{l}\text { Academic } \\
\text { leaders (e.g., } \\
\text { "one dean") }\end{array}$ & Principles & $\begin{array}{l}\text { Phase } 5 \text {, focus on con- } \\
\text { ceptions of research; } \\
\text { no gender noted }\end{array}$ \\
\hline
\end{tabular}

\section{FPT Levels of Gender Awareness}

FPT levels of gender awareness resulted from our assessment of the ways gender was included in the articles or book reviews. Throughout the process, we debated the necessity of including gender demographics and descriptors or names and the link among these items to Phase level assessments. The lack of article findings or conclusions related to gender when gender specific information was used to describe the sample/population or study site was judged to be gender unaware. The use of gender neutral names and labels led to our assessment of greater gender aware- 
ness. A mention of gender typically resulted in an assessment of Phase level 1, 2, 3 or 4; no reference to gender was assessed as Phase level 5, gender was not an issue or concern.

In terms of FPT phase designations, there were no Phase 1, 2 or 4 articles (see Table 6). Articles were clearly determined to be Phase 3 or Phase 5 . The majority of articles $(6$ of $9 ; 66 \%)$ were determined to be Phase level 5, no mention of gender was found. Three were assessed as Phase level 3. Gender was mentioned although it was not essential for understanding content; these were not articles about leadership and gender. Two of the Phase level 3 articles are based upon the same study (Understanding leadership strategies for addressing the politics of diversity and creating a web of support an important leadership strategy for advancing campus diversity). One was published in JHE, a US journal, and the other published in HE, an international journal.

Table 6: Article FPT awareness levels and year of publication

\begin{tabular}{lccccccc}
\hline & JHE & RevHE & US & HE & HEQ & INT'L & TOTAL \\
\hline Phase 1 & 0 & 0 & 0 & 0 & 0 & 0 & 0 \\
\hline Phase 2 & 0 & 0 & 0 & 0 & 0 & 0 & 0 \\
\hline Phase 3 & $2008(1)$ & 0 & 1 & $2008(1)$ & $2011(1)$ & 2 & 3 \\
\hline Phase 4 & 0 & 0 & 0 & 0 & 0 & 0 & 0 \\
\hline Phase 5 & $2008(1)$ & 0 & 1 & $2011(1)$ & $2008(3)$ & 5 & 6 \\
\hline Totals & 2 & 0 & $2014(1)$ & & 4 & 9 \\
\hline
\end{tabular}

It is important to note that book reviews, rather than the books themselves, were analyzed for FPT levels. Thus, the way the reviewer represented the book resulted in the FPT analysis for this research. However, a review of the book itself may have yielded a different analysis. The international journals contributed two reviews to our total of 16, both in 2011 (see Table 7), one identified as Phase 3 and one as Phase 5. While the majority of the US journal reviews were categorized as Phase 3, two reviews were identified as Phase 4 and one as Phase 5. Two reviews (13\%) which treated both gender and leadership were found to be characteristic of FPT Phase 4, focusing only on women, while two other reviews $(13 \%)$ were found to fit Phase 5 , as gender was not mentioned. None of the reviews were identified as either Phase 1 or Phase 2.

Table 7: Book review FPT awareness levels and year of publication

\begin{tabular}{lccccccc}
\hline & JHE & RevHE & US & HE & HEQ & INT'L & TOTAL \\
\hline Phase 1 & 0 & 0 & 0 & 0 & 0 & 0 & 0 \\
\hline Phase 2 & 0 & 0 & 0 & 0 & 0 & 0 & 0 \\
\hline Phase 3 & $2008(1)$ & $2008(6)$ & 11 & $2011(1)$ & 0 & 1 & 12 \\
& $2014(1)$ & $2011(1)$ & & & & \\
\hline Phase 4 & $2014(2)$ & & & 0 & 2 \\
\hline Phase 5 & $2008(1)$ & $2011(1)$ & 2 & 0 & $2011(1)$ & 1 & 2 \\
\hline Totals & 4 & 0 & 1 & 0 & 1 & 2 & 16 \\
\hline
\end{tabular}


Overall, there was no pattern of phase level and publication year (see Tables 6 and 7). For example, articles and book reviews did not indicate a change in gender awareness from 2008 to 2014.

\section{Conclusions}

The most surprising reality revealed through this study was the paucity of research about leadership in higher education in these premier journals, particularly in the US. As a result of our research, we know that relatively few articles published in both US and international research journals reviewed in this study address the study of leadership. We also know that few books reviewed in these same US and international journals address the study of leadership.

In terms of higher education leadership research published in these journals, the reviewed articles and book reviews indicate progress toward a multifocal or relational set of leadership perspectives, FPT Phase 5. Both men and women contribute as authors, use a variety of methods effectively, and focus on issues less related to gender than to social justice, democratic education, and other more global issues/concerns. Regardless of US or international forums, most articles explore the leadership concerns of upper-level university leaders - provosts, presidents, and deans. And, within the articles focused on leadership, there is no consistent pattern of thought or focus on methodology as defined by Tetreault (1987); however, principles of leadership, leadership practices, and procedural leadership concerns singularly and collectively can be found. Few patterns or differences can be found among the US and international journals reviewed in terms of these demographics.

Although there is a paucity of research on leadership in higher education, the research presented supports a disciplinary development of leadership well along its way to achieving gender awareness. The book reviews and articles reviewed show progress toward a multifocal or relational set of perspectives, FPT Phase 5. Gender issues or concerns are no longer part and parcel of the job of leadership and administration in higher education settings. Our reviews provide evidence for female administrators that "they have arrived."

One-third of the articles reviewed and the majority of book reviews were set in Phase 3, indicating that gender and leadership are still being examined, intentionally or not. The mention of gender, when research questions and findings neglect to address gender differences or realities, we believe shows a continuing underlying concern about gender and the ways in which it can impact leadership. It is possible that in some ways, the profession has "come a long way," and in other ways it has not. In terms of FPT methodology, principles and procedures do not need to include discussions of gender; but discussions of practice may, and those that do are more likely to be Phase 3.

\section{Implications for Theory}

Feminist Phase Theory (FPT) was a helpful framework for understanding the levels of gender awareness in the journal articles and book reviews examined in this study. With FPT we were able to see the ways in which gender was examined and/or reported by researchers exploring leadership in higher education. The components of FPT - content (what), structure (who), and methodology (how) - helped us frame the leadership focus of each study. Researchers focused their studies on top level university leaders and combinations of principles (philosophy), practices (leader behaviors), and procedures (ways of doing) applied to the process of leadership. This framework fosters comparisons and contrasts that are helpful in understanding the breadth and variety of leader work and levels of gender awareness. Settings or context, however, are not a part of this framework and may benefit from inclusion in some way. Where a person works - public/private, for-profit/non-profit - may be influential in terms of levels of gender awareness within content, structure, and methodology. 
Another issue linked to FPT is "goodness" of phases. Inherent in the history of FPT is movement through the 5 phases. Phase 1 - Male Dominant is just a phase, but many would evaluate it as a negative phase. It is devoid of gender awareness and solely based upon the "male model." In the same way, Phase 5 - Multi-focal or Relational is just a phase, but many would evaluate it as positive and the goal of development and gender awareness. We offer a different theoretical stance. Level 3 - Compensatory examines both male and female awareness. Through this examination learning occurs. Differences can be explored and debated. In fact, our research presented here is Phase 3. We are looking for gender because we believe that through examination of gender levels of awareness we can see where we are and what else we need to think about, dialogue on, or debate as we grow.

\section{Implications for Practice}

The findings of this study may be used to shape graduate education in higher education by revealing the current state of discourse regarding leadership and administration in peer-reviewed journals as well as elucidating how gender is represented in those same journals. Theoretically and practically, gender matters. The majority of students nationally are female (Lopez \& GonzalezBarrera, 2014). These students deserve a voice. They need to see themselves in what they read and experience. Given this reality, questions for classroom discussion can be telling. When faculty present leadership cases and students role play, what gender levels of awareness emerge? What happens when gender is ignored? What happens when it is clearly identified and discussed?

Additionally, we have questions about the ways the notion of disciplinary development might be linked to diversity and social justice concerns in addition to those of gender awareness. What might be revealed when a diversity phase theory or social justice phase theory were applied to program curriculums? In our classrooms, is diversity considered and how? Is social justice considered?

\section{Implications for Research}

A focus on understanding leadership as a disciplinary endeavor does not appear to be paramount within the higher education community associated with these journals. Neither of the higher education associations (ASHE or SRHE) publishing or promoting the journals examined in this study have a focus in their publications on higher education leadership, leaders, or administration. These associations may be missing opportunities to foster research on higher education leadership.

At a time when the study of leadership in general has exploded (Dihn et al., 2014; Rothman, 2016), why is there so little being written about it in the context of higher education? Expansion of the current study, either by including additional years to be surveyed or by adding more US and international journals to be examined, might provide further insight to this puzzling question. We also believe that FPT may be a very useful framework for examining additional disciplinary areas. Would the same findings emerge from a review of journal articles in administrator practitioner journals? Would teacher education journals or school administration journals benefit from a FPT analysis? What about hospital administration?

\section{Discussion}

These conclusions and implications for theory, practice, and research have shown us that FPT's levels of gender awareness are theoretically relevant, still a concern for researchers, and have the potential to be helpful for giving voice to students in our graduate programs. We also know that in these four journals a focus on leadership is limited. This leads us to question the congruence between the theory and practice of leadership. 
Leaders make a difference. They are essential and help organizations move forward. We also believe that organizations cannot afford to overlook or underrepresent half of their organization's workers (women). Women in leadership are needed; men in leadership are needed. We need to recognize that gender is influential. What happens when it is considered and what happens when it is ignored? How can we learn from these comparisons and make the best future possible for our organizations?

\section{References}

Aitchison, C. (2001). Gender and leisure research: The "codification of knowledge." Leisure Sciences, 23, $1-19$.

Andersen, M. L. (1988). Changing the curriculum in higher education. In E. Minnich, J. O'Barr, \& R. Rosenfeld (Eds.), Reconstructing the academy: Women's education and women's studies (pp. 36-68). Chicago, IL: University of Chicago Press.

Association for the Study of Higher Education. (n.d.). Retrieved from http://www.ashe.ws/?page=186

Baffoe, M., Asimeng-Boahene,L., \& Ogbuagu,B.C. (2014). Their way or no way: "Whiteness" as agent for marginalizing and silencing minority voices in academic research and publication. European Journal of Sustainable Development, 3(1), 13.

Bagilhole, B. (2002). The myth of superman: A feminist investigation of academic careers. In C. Weidmer (Ed.), Sound changes: An international survey of women's career strategies in higher education. (pp. 67-74). Zürich: UniFrauenstelle.

Barnett, R. C., Carr, P., Boisnier, A. D., Ash, A., Friedman, R. H., Moskowitz, M. A., \& Szalacha, L. (1998). Relationships of gender and career motivation to medical faculty members' production of academic publications. Academic Medicine, 73(2), 180-186.

Bornstein, R. (2008). Women and the college presidency. In J. Glazer-Raymo, Unfinished agendas: New and continuing gender challenges in higher education (pp. 162-184). Baltimore: Johns Hopkins University Press.

Bowker. (n.d.). Books in print. Retrieved from http://www.bowker.com/en-US/products/servlib bip.shtml

Bray, N. J., \& Major, C. H. (2011). Status of journals in the field of higher education. The Journal of Higher Education, 82(4), 479-503.

Brown. H. (1997). Equal opportunities policy. In H. Eggins, Women as leaders and managers in higher education (Society for Research in Higher Education; pp. 109-121). Bury St. Edmunds, Suffolk, Great Britain: St. Edmundsbury Press Ltd.

Budd, J. M. (1988). A bibliometric analysis of higher education literature. Research in Higher Education, 28(2), 180-190.

Buffalino Roland, C. \& Fontanesi-Seime, M. (1996). Women counselor educators: A survey of publication activity. Journal of Counseling and Development, 74(5), 490-494.

Chuppa-Cornell, K. (2005). The conditions of difficulty and struggle: A discovered theme of curriculum transformation and women's studies discourse. NWSA Journal, 17(1), 23-44.

Dinh, J. E., Lord, R. G., Gardner, W. L., Meuser, J. D., Liden, R. C., \& Hu, J. (2014). Leadership theory and research in the new millennium: Current theoretical trends and changing perspectives. The Leadership Quarterly, 25(1), 36-62.

Dominico, F., Fried, L.P., \& Zeger, S.L. (2009). So few women leaders. Academe, 95(4), 25-27.

Donaldson, J. F. \& Townsend, B. K. (2007). Higher education journals' discourse about adult undergraduate students. Journal of Higher Education, 78(1), 27-49.

Eagly, A. H. \& Carli, L. L. (2007). Through the labyrinth: The truth about how women become leaders (Center for Public Leadership). Boston: Harvard Business School Publishing Corporation. 
Eggins, H. (Ed.). (1997). Women as leaders and managers in higher education (Society for Research in Higher Education). Burry St. Edmunds, Suffolk, Great Britain: St. Edmundsbury Press Ltd.

Eichler, M. (1980). The double standards: A feminist critique of feminist social science. New York: St. Martin's Press.

Equality Challenge Unit. (2014). Equality in higher education: Statistical report 2014. London: Equality Challenge Unit. Retrieved from http://www.ecu.ac.uk/publications/equality-higher-educationstatistical-report-2014/

Evans, H. K., \& Bucy, E. P. (2010). The representation of women in publication: An analysis of Political Communication and the International Journal of Press/Politics. PS: Political Science \& Politics, 43(02), 295-301.

Friedan, B. (1963). The feminine mystique. New York: W. W. Norton \& Company.

Glazer-Raymo, J. (1999). Shattering the myths: Women in academe. Baltimore: Johns Hopkins University Press.

Glazer-Raymo, J. (2008). Unfinished agendas: New and continuing gender challenges in higher education. Baltimore: Johns Hopkins University Press.

Grunig, L. A. (2000). A feminist phase analysis of research on women in postmodern public relations. In D. Moss, D. Vercic, \& G. Warnaby (Eds.), Perspectives on public relations research (pp. 89-120). London \& New York: Routledge.

Hart, J. (2006). Women and feminism in higher education scholarship: An analysis of three core journals. Journal of Higher Education, 77(1), 40-61.

Herr Van Nostrand, C. (1993). Gender responsible leadership. Newbury Park: Sage.

Hune, S. (1998). Asian Pacific American women in higher education: Claiming visibility and voice. Washington, D.C.: Association of American Universities and Colleges.

Hunt, B., \& Harrington, C. F. (2010). The impending educational crisis for American Indians: Higher education at the crossroads. Indigenous Policy Journal, 21(3).

Hutchinson, S. R. \& Lovell, C. D. (2004). A review of methodological characteristics of research published in key journals in higher education: Implications for graduate research training. Research in Higher Education, 45(4), 383-403.

Jagsi, R., Guancial, E. A., Worobey, C. C., Henault, L. E., Chang, Y., Starr, R., ... \& Hylek, E. M. (2006). The "gender gap" in authorship of academic medical literature-a 35-year perspective. New England Journal of Medicine, 355(3), 281-287.

Johns Hopkins University Press. (n.d.). Retrieved from http://www.press.jhu.edu/journals/review of higher_education/

Kaufman, R. R., \& Chevan, J. (2011). The gender gap in peer-reviewed publications by physical therapy faculty members: A productivity puzzle. Physical Therapy, 91(1), 122-131.

Keamy, R. K. (2008). Crossing uncertain terrain: Messages from male academics. Gender and Education, 20(3), 267-279.

Kellerman, B., \& Rhode, D. L. (Eds.). (2007). Women and leadership: The state of play and strategies for change. San Francisco, CA: Jossey-Bass.

King, C. (1997). Through the glass ceiling: Networking by women managers in higher education. In H. Eggins, Women as leaders and managers in higher education (Society for Research in Higher Education; pp. 91-100). Burry St. Edmunds, Suffolk, Great Britain: St. Edmundsbury Press Ltd.

Kolb, D. M., Williams, J., \& Frohlinger, C. (2004). Her place at the table: A woman's guide to negotiating five key challenges to leadership success. San Francisco: Jossey-Bass. 
Kumashiro, K., Pinar, W., Graue, E., Grant, C., Benham, M., Heck, R., ... \& Luke, C. (2005). Thinking collaboratively about the peer-review process for journal-article publication. Harvard Educational Review, 75(3), 257-285.

Leahy, E. (2006). Gender differences in productivity: Research specialization as a missing link. Gender and Society, 20(6), 754-780.

Lopez, M.H., \& Gonzalez-Barrera, A. (2014). Women's college enrollment gains leave men behind. Retrieved from Pew Research Center http://www.pewresearch.org/fact-tank/2014/03/06/womens-collegeenrollment-gains-leave-men-behind/

Lougee, C. (1981). Women, history and the humanities: An argument in favor of the general curriculum. Women's Studies Quarterly, 9(1), 4-7.

Martin, L. J. (2012). Where are the women in ecology? Frontiers in Ecology and the Environment, 10(4), 177-178.

Mathews, A. L., \& Andersen, K. (2001). A gender gap in publishing? Women's representation in edited political science books. Political Science and Politics, 34(1), 143-147.

McIntosh, P. (1983). Interactive phases of curricular re-vision: A feminist perspective. New York: Andrew W. Mellon Foundation. (ERIC Document Reproduction Service No. ED 244 895).

Milam, J. H. (1991). The presence of paradigms in the core higher education journal literature. Research in Higher Education, 32(6), 651-668.

Minnich, E. K. (1990). Transforming knowledge (2nd ed.). Philadelphia: Temple University Press.

National Leadership Network. (1992). Strengthening support and recruitment of women and minorities to positions in education administration (Report No. PIP-92-1828). Washington, DC: U.S. Government Printing Office.

Ng, J. C., Lee, S. S., \& Pak, Y. K. (2007). Contesting the model minority and perpetual foreigner stereotypes: A critical review of the literature on Asian Americans in education. Review of Research in Education, $31,95-130$

Nidiffer, J. (2000). Pioneering deans of women: More than wise and pious matrons. New York: Teachers College Press.

Nidiffer, J. (2003). From whence they came: The contexts, challenges and courage of early women administrators in higher education. In B. Ropers-Huilman (Ed.), Gendered futures in higher education: Critical perspectives for change (pp. 15-34). Albany, NY: State University of New York Press.

Nidiffer, J., \& Bashaw, C. T. (Eds.). (2001). Women administrators in higher education: Historical and contemporary perspectives (SUNY Series, Frontiers in Education). Albany, NY: State University of New York Press.

Parsons, M., \& Ward, E. R. (2001). The roaring silence: Feminist revisions in the educational policy literature. Policy Studies Review, 18(2), 46-64.

Peña, E. V. (2014). Marginalization of published scholarship on students with disabilities in higher education journals. Journal of College Student Development, 55(1), 30-40.

Phillips, J. C., Ingram, K. M., Smith, N. G., \& Mindes, E. J. (2003). Methodological and content review of lesbian-, gay-, and bisexual-related articles in counseling journals: 1990-1999. The Counseling Psychologist, 31(1), 25-62.

Rigg, L. S., McCarragher, S., \& Krmenec, A. (2012). Authorship, collaboration, and gender: Fifteen years of publication productivity in selected geography journals. The Professional Geographer, 64(4), 491502.

Rothman, J. (2016, February 29). Shut up and sit down: Why the leadership industry rules. The New Yorker. Retrieved from http://www.newyorker.com/magazine/2016/02/29/our-dangerous-leadershipobsession 
Schmuck, P. A. (1987, April). Gender: A relative concept for educational leadership. Paper presented at the Annual Meeting of the American Educational Research Association, Washington, DC. (ERIC Document Reproduction Service No. ED 286 254)

Schmuck, P. A. (1993). Gender equity: A 20-year perspective. Keynote address delivered at the Gender Equity in Education Conference, Portland, OR. (ERIC Reproduction Service No. ED 373 423)

Schuster, M., \& Van Dyne, S. (1984). Placing women in the liberal arts: Stages of curriculum transformation. Harvard Educational Review, 54(4), 413-428.

Shakeshaft, C., \& Nowell, I. (1984). Research on theories, concepts and models of organizational behavior: The influence of gender. Issues in Education, 2(3), 186-203.

Shteir, R. (2013, February 1). Feminism fizzles. Chronicle of Higher Education, Chronicle Review, B6-B9.

Silverman, R. J. (1985). Higher education as a maturing field? Evidence from referencing practices. Research in Higher Education, 23(2), 150-183.

Silverman, R. J. (1987). How we know what we know: A study of higher education journal articles. Review of Higher Education, 11(1), 39-59.

Springer. (n.d.). Higher Education. Retrieved from http://ink.springer.com/journal/10734

Stanley, C.A. (2007). When counter narratives meet master narratives in the journal editorial-review process. Educational Researcher, 36(1), 14-24.

Terry, J. L. (1996). Authorship in "College and Research Libraries" revisited: Gender, institutional affiliation, collaboration. College and Research Libraries, 57(4), 377-383.

Tetreault, M. K. (1985). Feminist phase theory: An experience-derived evaluation model. Journal of Higher Education, 56(4), 363-384.

Tetreault, M. K. (1987a). Rethinking women, gender, and the social studies. Social Education, 51, 170-178.

Tetreault, M. K. (1987b). The journey from male-defined to gender-balanced education. Theory into Practice, 25, 227-34.

Tight, M. (2007). Bridging the divide: A comparative analysis of articles in higher education journals published inside and outside North America. Higher Education, 53, 235-253.

Tight, M. (2008). Higher education as tribe, territory and/or community: A co-citation analysis. Higher Education, 55(5), 593-605.

Townsend, B. K. (1993). Feminist scholarship in core higher education journals. The Review of Higher Education, 17(1), 21-41.

Twombly, S. B. (1991). New directions for studying women in higher education: Lessons from feminist phase theory. Initiatives, 54(1), 9-17.

Twombly, S. B. (1993). What we know about women in community colleges: An examination of the literature using feminist phase theory. Journal of Higher Education, 64(2), 186-210.

Van Voorhis, R., \& Wagner, M. (2001). Coverage of gay and lesbian subject matter in social work journals. Journal of Social Work Education, 37(1), 147-159.

Ward, K., \& Grant, L. (1996). Gender and academic publishing. In J. C. Smart (Ed.), Higher education: Handbook of theory and research, Vol. 11 (pp. 172-222). New York: Agathon Press.

Wells, R. S., Kolek, E., Williams, L., \& Saunders, D. B. (2015). How we know what we know: A systematic comparison of research methods employed in Higher Education journals, 1996-2000 v. 2006-2010. Journal of Higher Education, 86(2), 171-198.

White, K., Bahilhole, B., \& Riordan, S. (2012). The gendered shaping of university leadership in Australia, South Africa, and the United Kingdom. Higher Education Quarterly, 66(3), 293-307. 
Wiley, (n.d.). Higher Education Quarterly. Retrieved from http://www.wiley.com/WileyCDA/WileyTitle/productCd-HEQU.html

Wolverton, M., Bower, B. L., \& Hyle, A. E. (2009). Women at the top: What women university and college presidents say about effective leadership. Pathways to Leadership Series. Sterling, VA: Stylus Publishing.

Zichy, S. (2001). Women and the leadership q: Revealing the four paths to influence and power. New York: McGraw-Hill.

\section{Biographies}

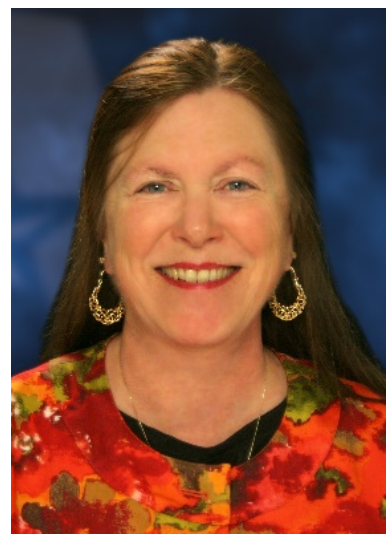

Adrienne E. Hyle is a retired professor. Most recently she served as chair of the Department of Educational Leadership and Policy studies at the University of Texas at Arlington. She also worked in the College of Education at Oklahoma State University where she served most recently as Associate Dean for Research and Graduate Studies and Outreach. She advised many pre-k-20 doctoral students and taught courses in change k-20 leadership.

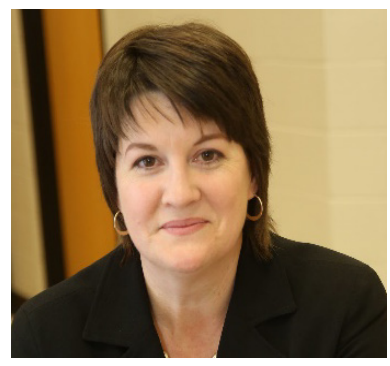

Peggy M. Delmas is an assistant professor in the Department of Leadership and Teacher Education at the University of South Alabama in Mobile, Alabama, where she teaches courses in higher education law, student development theory, and digital leadership. Her research interests include gender and leadership and global education.

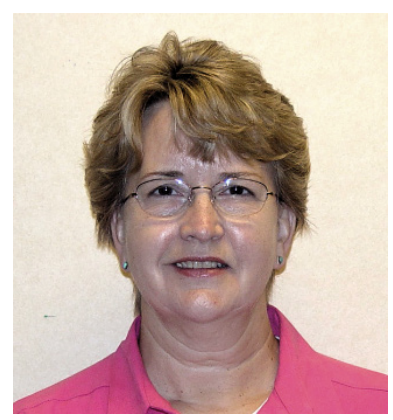

Bernita L. Krumm is an emeritus faculty member of the College of Education at Oklahoma State University, Stillwater, Oklahoma. Her research focuses on leadership and gender in education, school/community collaboration, and American Indian education. She is a former P-12 educator. 